\title{
The Impact of External Integration and Internal Integration to Product Innovation and Competitive Advantage on Small and Medium Enterprises (SMEs)
}

\author{
${ }^{1}$ Chamdan Purnama, ${ }^{2}$ Ludi Wishnu Wardana, ${ }^{3}$ Yusriyah Rahmah, ${ }^{4}$ Dinda Fatmah, \\ ${ }^{5}$ Mirhamida Rahmah \\ 1,4,5School of Economics Al-Anwar Mojokerto, Indonesia \\ ${ }^{2}$ Faculty of Economics, State University of Malang, Indonesia \\ ${ }^{3}$ Faculty of Computer Science, University of Brawijaya Malang
}

\begin{abstract}
This study aims to analyze the influence of external integration and internal integration to product innovation and competitive advantage. The research was conducted on a sample of 180 manager small and medium enterprises (SMEs) in East Java clothing taken with stratified cluster sampling technique. Selection of sample areas based on areas that have the potential development of the industry. Data collection was done by using questionnaire that has been tested for its validity and reliability. Data analysis used Structural Equation Modeling (SEM) analysis with help of AMOS version 21 program. Based on the analysis of SEM, it was found that the first, external integration influence on product innovation SMEs and affect the competitive advantage of SMEs. Second, the internal integration effect on product innovation SMEs and affect the competitive advantage of SMEs. Third, product innovation SMEs effect on the competitive advantage of SMEs. In this respect, the company needs to build a collaboration of external integration and internal integration in order to improve product innovation and competitive advantage of SMEs.
\end{abstract}

Keywords: External integration (EI), Internal integration (II), Product innovation (PI), Competitive advantage (CA), Small and medium enterprises (SMEs)

\section{Introduction}

The business world is currently growing and more and more competitors are unavoidable. The existence of competition makes the company exposed to various opportunities and threats both from within the country and abroad. Because of this intense competition the company must have a CA in order to survive and continue to develop their business. Brun et al., (2008) states that CA is owned by a company can be expected to result in a consumer satisfaction, because the CA it has is a reflection that the products offered meet the needs and desires of consumers, and a positive score in the eyes of consumers. The CA is the heart of marketing performance to the competition (Purnama and Subroto, 2016; Porter, 1996). The setting is a good strategy the key to success for the company to be in the forefront with anticipation in the market competition (Tarabieh et al., 2015). Innovation can be used as a strategy to achieve competitive advantage.

(Gray et al., 2002) suggests that the innovation capability of a company will guarantee the company's ability to compete. The company's success in maintaining product sales lies in its ability to innovate. Supply chain management (SCM) is the expansion and development of the concept and meaning of logistics management, whose role in regulating the flow of goods between the company and growing concerns to things that are required by the customer (Indrajit and Djokopranoto, 2006). Generally, there are two types of integration, namely the EI and II. EI is the integration of logistics activities 
which exceed the limits beyond the company. Meanwhile, the II of the cross-functional integration within an enterprise, as reflected by the level of activity of logistics functions, which are interconnected with the scope of other functions (Pituringsih, 2010). II shows the extent how companies can build organisational applied, etiquette and behaviors in synchronous process can be managed to satisfy customer desires (Paulraj et al., 2004).

Integration external and II is widely accepted because of its capability to increase performance, like grade, fee, consignment and smoothness (Wong et al., 2011; Droge et al., 2012; Prajogo and Olinger, 2012). However, results of several studies are still few studies linking of the EI and II towards PI and CA, especially SMEs in East Java.

Consequently this research want to determine so analyses what is the influence II to PI and the effect to CA of SMEs in East Java.

\section{Literature Review}

\subsection{External Integration and Internal Integration}

According Jebarus (2001) supply chain management (SCM) is a further development of distribution management products to meet consumer demand. By Indrajit and Djokopranoto (2006) SCM is the expansion and development of the concept and meaning of logistics management, whose role in regulating the flow of goods between the company and growing concerns to things that are required by the customer. SCM is an approach used to achieve integration of more efficient organisation of suppliers, manufacturer, distributor, retailer and customer.

From the explanation above researchers can conclude that SCM is a set of approaches to streamline and streamline the integration of suppliers, manufacturing, warehouse and storage, so that the goods are produced and distributed in the right amount, the right location, the right time, to minimize costs, lower volume waste and provide services to the customer's satisfaction. In this study, SCM split into two types of integration, namely the integration of external and II. EI refers to the extent to which a company can partner with other members of the supply chain (customers and suppliers) to develop strategies between organisations, practices, procedures, and behavior in the process of collaboration, synchronization, and can be managed to meet the needs of customers with indicators covering relations suppliers, raw material quality, supply, customer complaint, customer satisfaction, and customer relations. While the II shows the extent to which a company can build internal cooperation as reflected through information sharing of various departments within the company, such as production department, packing, warehousing, distribution, and transportation with indicators which include product development, production planning, quality control, quality production, distribution and quality of information (Paulraj et al., 2004;, Vijayasarathy, 2010; Droge et al., 2012).

While in this study indicators use as a guidance for researcher, using tools developed by (Aloini and Martini, 2013, Wong et al., 2011) for the integration of external variables with indicator (supplier relationships, quality of raw materials, supply risk, customer complaint, customer satisfaction, and customer relationship) and variable II with indicators (product development, production planning, quality control, quality of production, distribution, and quality information)

\subsection{Product Innovation}

Robbins and Coulter (2010) innovation is the process of turning creative ideas into a product or method useful work. PI by Kartikasari (2014: 56) is the result of development of new products by companies or industries, either existing or not. PI may include changes in design, components and product architecture. (Kasali, 2010) describes the innovation is the ability to see things in a new way and sometimes unusual. Anshori (2010) argues that innovation is the summation to the question why and how. Hills (2008: 11) defines innovation as an idea, practice or object that is considered new by an individual or a unit other users. According Machfoedz (2004: 24) points out that the 
innovation of products consists of four elements, namely the discovery, development, duplication and synthesis.

From the explanation above the researchers to conclude that PI is a change that is related to increasing or improving existing resources, modify to make something of value creating new things are different, converting a material into a resource and combining each source power into a new configuration that is more productive.

While this research indicator in use is the discovery, development, duplication and synthesis developed by Machfoedz (2004).

\subsection{Competitive Advantage}

CA according to Goyal (2001) is the company's ability to profit in profits that can be achieved by support market in same industry. Firm that have CAs had capability to know the difference and changes structural and knew the effective strategies of marketing. Competitive strategy intended to maintain profitability and lasting position in the face of competition. Developing CA of the value created by the company that is able to customers or buyers. According to Kotler (2005: 68) the CA for the acquisition obtained by giving a greater customer value, through a small fee or by providing more appropriate benefits at a higher price. Measurement of CA in the study of Li et al., (2006) used a dimensional measurement of CA in research among others using delivery dependability, product innovation and time to market. Some of the indicators used to measure CA is the uniqueness of the product, product quality and competitive price (Setiawan et al., 2012: 14).

In this study were measured with a CA in price, product quality, delivery dependability and time to market. These measurements as it has been used in the study (Bashor and Purnama, 2017; Setiawan et al., 2012; Li et al., 2006 and Thatte, 2007).

\section{Research Methodology}

Generally, this study aims to describe and analyze the influence of EI with indicators (supplier relationships, quality of raw materials, supply risk, customer complaint, customer satisfaction, and customer relationship) and II with indicator (product development, production planning, quality control, quality of production, distribution, and quality information) to PI with indicators (invention, development, duplication, and synthesis) and their impact on CA with indicators (price, product quality, delivery dependability, and time to market According to the purpose, this research designed as an explanatory research. The facile results in this study are supposed can provide an explanation on how CA is influenced by some factors, which is product innovation, EI and II.

Total population in the study was the manager of clothing SMEs in the region of East Java province, consisting of 38 local District / City Government. While the sample is a number of 180 managers, according Ferdinand (2014) respondent sample size that fits in the SEM analysis was around 100 200, further advised the respondent sample size of at least as much as 5 to 10 times of the number of indicators in the latent variable. While the sample of respondents in this study is 20 times the indicator variable 9 totaling 180 respondents. The sample selection is based on local area that potentially industrial development (industrial centers). The Ministry has set a small industrial centers for the entire region, which can be used as a basis for determining the sample area. Prepared in accordance directory, the center of industrial development in the area, business groups Indonesia East Java small industrial clothing consists of five areas, namely Tulungagung district, Bangkalan, Mojokerto, Mojokerto and Sidoarjo. Data is collected using a questionnaire that has collected validity and reliability. Data analysis using SEM analysis with the help of AMOS version 21 program.

\section{Data Analysis and Interpretation}

\subsection{Results Test Validity}


The instrument validity test was given to 180 respondents, and the results were analyzed using correlation product moment person. The results are compared with rtable at a significance level of $5 \%$ with $n=180$, and known to be rtable $=0.1455$. The results of the validity test show the results of calculating all questionnaire items from the variables EI, II, PI and CA having a value greater than rtable $=0.1455$. Thus all questionnaire items for variables EI, II, PI and CA are considered valid as a measurement tool and can be used to obtain the data needed in this study.

\subsection{Results Test Reliability}

After the validity test passed by the reliability test to determine the extent to which research instruments are reliable. The criterion is if the alpha correlation results are greater than 0.600 then the instrument can be said to be reliable. Summary of reliability results.

Summary results of reliability tests demonstrate the reliability values of Cronbach's Alpha variables EI, II, PI and CA have a greater value than rtable $=0.600$. Thus the whole item questionnaire for variables EI, II, PI and CA is considered to be reliable. Reliability of less than 60 is generally considered poor, their reviews in the range of 0.7 are acceptable, and their reviews of more than 0.8 are good (Penniston et al., 2017).

\subsection{Loading Factor Confirmatory Testing Results Analysis, Critical Path Ratio and Coefficient}

This research uses analysis factor and regression models with SEM. Based on results of the model testing, the confirmation factor and critical ratio are obtained as follows:

\subsection{External Integration}

This uses factor analysis and regression models with SEM. Based on the results of the model testing, the confirmation factor and critical ratio are obtained as follows:

Table 1: Regression Weight (Loading Factor Confirmatory) Standardized Estimate (SE) and Critical Ratio (CR) Indicators of Factor External Integration

\begin{tabular}{|c|c|c|c|c|c|}
\hline No & Indicators & $\begin{array}{l}\text { SE (Loading } \\
\text { Factor) good } \\
\text { of fit }>0,4\end{array}$ & $\begin{array}{l}\text { CR good } \\
\text { of fit > } \\
1,96\end{array}$ & $\begin{array}{l}\text { Probability } \\
(P) \text { good of } \\
\text { fit }<0,05\end{array}$ & Specification \\
\hline 1 & Supplier Relationship & 0.854 & 2.114 & 0.035 & good \\
\hline 2 & Quality of Raw Materials & 1.000 & & 0.000 & good \\
\hline 3 & Supply Risk & 0.283 & 3.455 & 0.000 & not good \\
\hline 4 & Customer Complaint & 1.161 & 2.932 & 0.026 & good \\
\hline 5 & Customer Satisfaction & 1.209 & 2.932 & 0.003 & good \\
\hline 6 & Customer Relationship & 1.563 & 3.263 & 0.001 & good \\
\hline
\end{tabular}

Sources: Primary data are processed

The test results presented in table 1 , it was found that six indicators can be used as a variable measure in explaining EI (supplier relations, raw material quality, supply risk, customer complaints, customer satisfaction, and customer relations).

\subsection{Internal Integration}

The results and critical confirmation factor loading ratio on job satisfaction are carefully as follows: 
Chamdan Purnama, Ludi Wishnu Wardana, Yusriyah Rahmah, Dinda Fatmah, Mirhamida Rahmah

The Impact of External Integration and Internal Integration to Product Innovation and Competitive Advantage on Small and Medium Enterprises (SMEs)

Table 2: Regression Weight (Loading Factor Confirmatory) Standardized Estimate (SE) and Critical Ratio (CR) Indicators of Factors Internal Integration

\begin{tabular}{|l|l|l|l|l|l|}
\hline No & Indicators & $\begin{array}{l}\text { SE (Loading } \\
\text { Factor) good } \\
\text { of fit } \mathbf{0 , 4}\end{array}$ & $\begin{array}{l}\text { CR good } \\
\text { of fit } \\
\mathbf{1 , 9 6}\end{array}$ & $\begin{array}{l}\text { Probability } \\
\text { (P) good of } \\
\text { fit }<\mathbf{0 , 0 5}\end{array}$ & Specification \\
\hline 1 & Product Development & 1.000 & & 0.000 & good \\
\hline 2 & Production Planning & 0.406 & 2.222 & 0.026 & good \\
\hline 3 & Quality Control & 0.800 & 4.329 & 0.000 & good \\
\hline 4 & Quality of Production & 0.914 & 2.234 & 0.000 & good \\
\hline 5 & Distribution & 0.908 & 4.360 & 0.000 & good \\
\hline 6 & Quality Information & 1.057 & 4.726 & 0.000 & good \\
\hline
\end{tabular}

Sources: Primary data are processed

The test results presented in table 2, it was found that the six indicators, all of which can be used as a measure in explaining together variable II, namely: (product development, production planning, quality control, quality of production, distribution, and quality information). From the sixth indicator that is most able to explain variable II is quality information, and product development, followed by quality production, quality control and then further distribution of the latest production planning

\subsection{Product Innovation}

The results of the confirmation factor and the critical success ratio in careful effort are as follows:

Table 3: Regression Weight (Loading Factor Confirmatory) Standardized Estimate (SE) and Critical Ratio (CR) Indicators of Factors Product Innovation

\begin{tabular}{|l|l|l|l|l|l|}
\hline No & Indicators & $\begin{array}{l}\text { SE (Loading } \\
\text { Factor) good of } \\
\text { fit }>0,4\end{array}$ & $\begin{array}{l}\text { CR good } \\
\text { of fit } \\
1,96\end{array}$ & $\begin{array}{l}\text { Probability } \\
(P) \text { good of } \\
\text { fit }<0,05\end{array}$ & Specification \\
\hline 1 & Invention & 0.791 & 3.507 & 0.000 & good \\
\hline 2 & Development & 0.910 & 3.705 & 0.000 & good \\
\hline 3 & Duplication & 0.784 & 3.571 & 0.000 & good \\
\hline 4 & Synthesis & 1.000 & & 0.000 & good \\
\hline
\end{tabular}

Sources: Primary data are processed

The test results presented in table 3, it shows that all four indicators can all be used as PI measures in explaining variables, namely: (discovery, development, duplication, and synthesis). The four indicators together can explain the PI variable and from the four indicators that are most able to explain the variables are synthesis, then development is followed and the latest findings are duplicates.

\subsection{Competitive Advantage}

Results containing confirmation factors and critical success ratios in careful effort are as follows:

Table 4: Regression Weight (Loading Factor Confirmatory) Standardized Estimate (SE) and Critical Ratio (CR) Indicators Of Factor Competitive Advantage

\begin{tabular}{|l|l|l|l|l|l|}
\hline No & Indicators & $\begin{array}{l}\text { SE (Loading } \\
\text { Factor) Good } \\
\text { Of Fit }>0,4\end{array}$ & $\begin{array}{l}\text { CR Good Of } \\
\text { Fit }>1,96\end{array}$ & $\begin{array}{l}\text { Probability (P) } \\
\text { Good Of Fit }< \\
0,05\end{array}$ & Specification \\
\hline 1 & Price & 1.000 & & 0.000 & good \\
\hline 2 & Product Quality & 0.144 & 2.616 & 0.009 & not good \\
\hline 3 & Delivery Dependability & 1.368 & 7.214 & 0.000 & good \\
\hline 4 & Time To Market & 0.148 & 2.534 & 0.011 & not good \\
\hline
\end{tabular}




\section{Sources: Primary data are processed}

Test results presented in table 4. The results of the tests above show that of the four indicators, only two that can be used as a measure of CA in explaining variables are: shipping dependence and price. The two indicators are jointly able to explain the variables and CA from the two indicators that are most able to explain the variables are dependence on shipping, and then the price.

\subsection{Testing Results (Confirmatory Factor Analysis)}

Having to do tests on the foregoing assumptions and found that the model has a good alignment, then analyzed the data to get a clear picture of each variable. The results of the analysis will be undertaken for each variable in the study can be described as follows:

The test results confirmatory factors and influence the path coefficient EI variables with indicators (supplier relationships, quality of raw materials, customer complaint, customer satisfaction, and customer relationship), II with indicators (product development, production planning, quality control, quality of production, distribution, and quality information) to PI with indicators (invention, development, duplication, and synthesis) and their impact on CA with indicators (price and delivery dependability). Broadly speaking, it can be seen in figure 1 below:

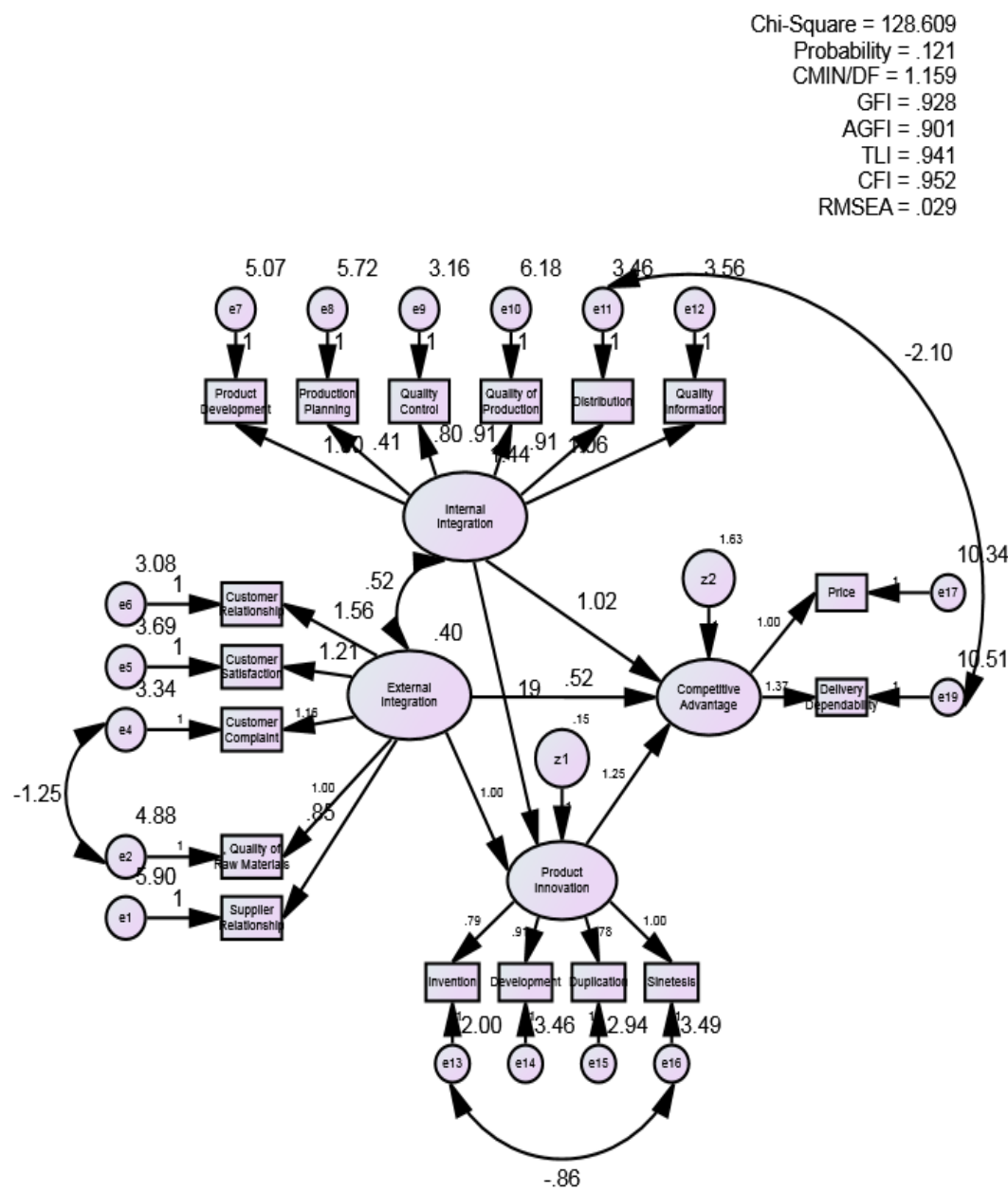

Figure 1: Confirmatory Factor and Coefficient Line Effect of Variable External Integration, Internal Integration and Product Innovation Against Competitive Advantage

Sources: Primary data are processed 
Chamdan Purnama, Ludi Wishnu Wardana, Yusriyah Rahmah, Dinda Fatmah, Mirhamida Rahmah

The Impact of External Integration and Internal Integration to Product Innovation and Competitive Advantage on Small and Medium Enterprises (SMEs)

\subsection{Hypothetical Testing Results}

Results of calculations as presented in table 6

Table 6 : Results of Testing Influence of Variables External Integration, Internal Integration and Product Innovation Against Competitive Advantage

\begin{tabular}{|l|l|l|l|l|l|l|}
\hline NO & Variabel Coefficient & SE & CR & P & Specification \\
\hline 1 & $\begin{array}{l}\text { Product_Innovation } \\
\text { External_Integration }\end{array}$ & 1.000 & & & 0.000 & Significant \\
\hline 2 & $\begin{array}{l}\text { Product_Innovation } \\
\text { Internal_Integration }\end{array}$ & 0.190 & 0.653 & 3.242 & 0.021 & Significant \\
\hline 3 & $\begin{array}{l}\text { Competitive_Advantage } \\
\text { External_Integration }\end{array}$ & 0.518 & 2.690 & 2.236 & 0.041 & Significant \\
\hline 4 & $\begin{array}{l}\text { Competitive_Advantage } \\
\text { Internal_Integration }\end{array}$ & 0.034 & 1.015 & 3.983 & 0.004 & Significant \\
\hline 5 & $\begin{array}{l}\text { Competitive_Advantage } \\
\text { Product_Innovation }\end{array}$ & 1.245 & 2.265 & 2.705 & 0.048 & Significant \\
\hline
\end{tabular}

Sources: Primary data are processed

Judging from table 6 above, it was found that 1). EI significant effect on PI with coefficient 1,000 lane 2). II significant effect on PI with the coefficient of 0.190 lane 3). EI significant effect on the CA with coefficient 40518 lines). II significant effect on the CA with path coefficient value of 0.034 and 5). PI significant effect on the CA with path coefficient value of 1.245.

\subsubsection{Effect of External Integration and Internal Integration of the Product Innovation}

From table 6, it can be concluded that the test results with SEM analysis performed using AMOS 21 shows that the EI has significant positive effect on PI.

This finding shows that the results are in accordance with what expressed by Wu (2013) found that EI and II affect on innovation products. Wong et al., (2013), which states that the EI has a positive influence on PI. Furthermore, Wong et al., (2013) Stated that EI has the ability to acquire information, knowledge sharing, coordination efficiently, and facilitate new PI with collaboration between external parties and EI helps improve the capabilities and resources normally owned by other parties, such as suppliers and customers (Aloini and Martini, 2013), where staff of purchasing and manufacturing departments need to work with suppliers to ensure suppliers understand the design and manufacturing process of new products according to needs.

Song et al., (2017) states the importance of EI, integration moderates the relationship between customers and business performance, the relationship between supplier integration and operational performance, and the relationship between time to market and business performance. In addition, customer and supplier integration fully improves operational and business performance by reducing time to market, while increasing customer integration with full operational performance by shortening time to market. Gatz EI allows companies to gain knowledge about the needs of consumers (Ragatz et al., 1997). Through the integration of the value chain upstream (Ettlie and Reza, 1992). In addition EI support supplier involvement in new product development process (Ragatz et al., 1997; Koufteros et al., 2005), which allows the company to focus on digging new products and technological knowledge of the supplier (Petersen et al., 2005) that complements internal capabilities (Ragatz et al., 1997).

Better regarding the influence of II to PI. According Dangelico et al., (2017) the EI of resources, integration of internal resources, and the development of resources and reconfiguration) affecting changes / updates to the ability regular-oriented sustainability (ability of innovation and design capabilities). The results of the study support research Yee \& Ooi (2008) and share information 
among supply chain partners, and establish supply chain collaboration (Schmelzle and Tate, 2017; Cilibertietal, 2016).

This study is in line with the theory of ambidexterity, that the EI and II complement each other to facilitate business processes. As it is known, that the EI known to be more effective in influencing the time-based performance and flexibility as well as building cooperation with suppliers and customers (Ettlie and Reza, 1992). While the II is superior in terms of quality, costs, as well as communication, collaboration and sharing of information between departments within the company (2010, Wong et al., 2009). The decision of new product development in the company relies on information obtained from suppliers and customers, known as the EI, and the information will be converted into a reference or insight that is very useful when going on PI internally when supported by effective interaction between the EI and II. When EI and II interact, knowledge or assets owned by the supplier and the customer will be incorporated into the PI efforts. Therefore, to ensure the development of effective innovation, companies are advised to increase its internal capacity to absorb knowledge and external information (Tracey, 2004). The results of this study have important implications for research and also practices in the field of supply chain integration and PI.

\subsubsection{Effect of External Integration and Internal Integration to Competitive Advantage}

From table 6 , it can be concluded that the test results with the analysis sem who performed using the amos 21 shows that the EI and II significant positive effect on the CA.

These findings indicate that the results were in line with what is Liu et al., (2017) based on the analysis of the relationship between integration between departments and service innovation has a significant positive correlation level. Integrating resources, internal and external competency, adopted a "direct innovation" and the flow of knowledge within the organisation, complementary competencies and fast and seamless communication with customers to enable organisations to obtain external knowledge and to improve innovative development to maintain a competitive advantage. In the era of economic globalisation with the knowledge and network economy, growth companies are facing new challenges. In such a situation, enterprises should emphasise the integration of internal network resources and reduce business risk by developing external network relationships to improve performance. Forms of II that can provide the sustainable and synergistic effect of warding off competition for now. Gunaratne \& Hoover (2001) states have competitive products and services, also supply chain right to the customer is not enough in today's market environment, the supply chain should be on the right customers. Relational customers, combined with the operations of the company and the customer's operations will create a supply chain demand. Business success SMEs sustainable depends on many other factors, such as the ability of the supplier and customer integration (Tehseen and Ramayah, 2015).

This research support study (Rahmah, M., \& Fatmah, D., 2018; Li et al., 2006) found that the integrity of the implementation of external and internal integrity can lead to improvement of excellence compete and improve organisational performance. To build CA depends not only on internal factors but also influenced by external factors (Restrepoet al., 2016). The survival and growth of SMEs can be difficult in today's competitive business environment and global markets. That is a challenge to deliver the right products, services promptly and with the lowest possible cost to right customers. These challenges emphasise the importance of managing cross-border relationships between business partners. To gain a competitive advantage, an effective tool for SMES is SCM (Thooet al., 2017). The results of the Sales et al., (2016) Studies show there are many factors that drive the development of Product Innovations, both internally and externally to the company. In internal factors, the most important is the prospect of competitive advantage, reduction in costs, market benefits, increased reputation as well as innovation opportunities. In external factors, the most important are regulations in the environment - currently or anticipated - and demand on the market. In the results, this study provides evidence that the most relevant things are cost savings, achievement in competitive advantage, increasing share in the market, increasing sales, increasing 
turnover, higher profits, better reputation, increased exports and higher productivity. According to Quang et al., (2016) from the perspective of supply chain management, the specific critical dimensions : procurement, internal logistics and distribution. Therefore, there is a need to change the thinking of today's organisations that focused on the enterprise, and develop it into an interorganisational behaviour involving customers, suppliers and other stakeholders.

Today, the knowledge economy more focused on developing integrated systems that been recognised as one of the most effective integration systems. In turn, the process, which is based on interdependence and cooperation from economic entities, enables stable economic relations, synergistic effects and CA growth (Pustynnikova \& Uskova, 2017).

Findings Sales et al., (2016) building collaborative networks and to improve the flow of knowledge, both inside and outside the company, cross-functional integration and the development of resources and the ability to influence the success of the development of PI. The development of PI. which in turn will increase the CA (Garengo \& Panizzolo, 2013). According to (Carraresi et al., 2016) results show that marketing, networking, and innovation capabilities directly and positively affect performance. SMEs benefit from selling their products on the national market. Network capability plays a dual role: It has a direct positive influence on performance and also an indirect effect on the ability to obtain information about markets and supply chain agents. The market and consumer information obtained is very valuable in improving marketing capabilities and improving performance

\subsubsection{Effect of Product Innovation to Competitive Advantage}

From Table 6, it concluded that the results of testing with SEM analysis carried out using AMOS 21 showed that PI had a significant positive effect on CA.

These findings show that the results are in line with what was expressed by Kennedy et al., (2017) PI has a significant and positive impact on CA. Carraresi et al., (2016) the results of his research shows that the ability to innovate is directly and positively affect performance. Bermúdez et al., (2017) the concept of open innovation chain. This concept will be an alternative for the growth of small and medium-sized companies, ranging from the integration of their actors to solve the real needs of the market. Khan et al., (2017) Innovation is important for SMEs to survive in market and maintain a competitive advantage. Ability to obtain information about markets and supply chain agents. The market and consumer information obtained is very valuable in improving marketing capabilities and improving performance. On the other hand company that have more capacity to innovate will be able to develop a CA in order to achieve the performance (Daneels, 2002). These advantages can not be separated from the development of product innovations produced, so it will have the advantage in the market which in turn will win the competition. Innovation gives companies the possibility to create and use their capabilities to support business and long-term performance (Teece, 2007). Innovation when it success can make it harder for companies to replicate the external environment and allow them to maintain excellence (García-Morales et al., 2006). Therefore, innovation will affect the company's CA and performance. Under conditions of a rapidly changing environment, saying that the CA is determined by the creativity and innovation that can satisfy the desires of customers better than the competition. Gray et al., (2002) says the innovation capability of a company will ensure the company's ability to compete. (O'Regan and Ghobadian, 2005), see the innovation is a new idea that can create added value for the company.

Through innovation, the company hopes to create a product that is completely new, or other previously or create a product which is an improvement of the product which have been there before. In consuming a product, consumers are not only limited to see the value or function of a product that is needed, but consumers also pay attention to whether the selected products add value or advantages compared with other similar products. Desire is what should be understood by the manufacturer as the foundation for the innovation process. Innovating, companies will be successfully responding to their environment and develop skills where this can have an impact on 
the overall marketing performance. Utaminingsih (2016) states that innovation has a positive and significant effect on marketing performance. Usvita (2015) states that CA has a significant positive effect on marketing performance. Research (Titahena et al., 2012) found empirical evidence which states that there is a significant positive relationship and supports the relationship between CA for marketing performance. Research (Titahena et al., 2012) found empirical evidence that states that there is a significant positive relationship and support of the existence of a relationship between a CA to marketing performance. It means that if CA marketing performance will increase and vice versa. Innovation is one of the key aspects of company performance, if the competitive environment is getting tougher. Another opinion is from (Gray et al., 2002) suggests that the innovation capability of a company will guarantee the company's ability to compete. O'Regan and Ghobadian (2005) to see the innovation is a new idea that can create added value for the company. Robbins and Coulter (2010) innovation is the process of changing ideas - creative ideas into a product or method useful work. Kasali (2010) describes the innovation is the ability to see things in a new way and sometimes unusual.

According Hubeis (2005: 69) explains that PI is a change that is related to increasing or improving existing resources, modify to make something of value creating new things are different, converting a material into a resource and combining each source power into a new configuration that is more productive, either directly or indirectly in an effort to gain a competitive advantage. Innovation can also be created as the company saw a lot of competitors are emerging that the company is able combine competitors excellence into a new advantage for the company. CA has been achieved by the company should be maintained due to their advantages more and more competitors who pay attention to the point unguarded firms, therefore the company should continue to be consistent in maintaining its superiority (Russell \& Millar, 2014). CA can also be seen through customer evaluations that can be created by firms through service facilities that can accommodate all sorts of complaints or suggestions aimed at consumers to the company for the sake of improvement toward a higher quality. The setting is a good strategy the key to success for the company to be in the forefront with anticipation in the market competition (Tarabieh et al., 2015). At present innovation has become an important factor for entrepreneurs and companies in ensuring sustainability and even the survival of companies in global business (Costa \& Ramos, 2015).

\section{Conclusion and Recommendations}

Based on the results of the research and discussion above, it can be concluded that EI represented by (customer relationship, and customer satisfaction, followed by customer complaint, then the quality of raw materials and most recently supplier relationship) influence on PI represented by (synthesis, then development, followed by his most recent invention and are duplications) and of the EI effect on the CA represented by (delivery dependability, and then price). EI (integration of customers and suppliers) increase operational performance and business completely by reducing time to market, while the integration of customers improve fully operational performance by shortening time to market.

II represented by (quality information, and product development, followed by quality of production, then quality control further distribution of the most recent and production planning) effect on PI represented by (synthesis, then development, followed by his most recent invention and are duplications). And II affect the CA represented by (delivery dependability, and then price). EI and II is widely accepted because of its ability to improve operational performance, such as quality, cost, delivery, and flexibility. So as to enhance the innovation capability and its ability to compete.

PI represented by (synthesis, then development, followed by his most recent invention and are duplications) affect the CA represented by (delivery dependability, and then price). The innovation capability of a company will guarantee the company's competitive ability and success of the company in order to maintain sales of its products lies in its ability to innovate. 


\section{Acknowledgements}

The authors are grateful to School of Economics Al-Anwar Mojokerto, Indonesia and Faculty of Economics, State University of Malang, Indonesia, and Faculty of Computer Science, University of Brawijaya Malang. Special thanks to the Editors of the Journal for the many valuable comments on the previous version of the paper which has improved its quality and content to the present state.

\section{References}

- Aloini, D. \& Martini, A. (2013). Exploring the exploratory search for innovation: A structural equation modelling test for practices and performance. International Journal of Technology Management, 61(1), 23-46.

- Anshori, M. Y. (2010). Pengaruh orientasi pasar, intellectual capital, dan orientasi pembelajaran terhadap inovasi. Jurnal Manajemen Bisnis Sekolah Tinggi Ilmu Ekonomi Perbanas Surabaya, 3(3), 317-329. Crossref

- Bashor, C., \& Purnama, C. (2017). Factors Affecting Performance Manager and Its Impact on Competitive Advantage: Studies Small Medium Enterprises (SMEs) in The Shoes Industry Mojokerto East Java Province. Mediterranean Journal of Social Sciences, 8(4), 153-162. Crossref

- Bermúdez, A. M., Riveros, C., \& Calderon, M. (2017). Innovation Open Chains: A Model of Competitiveness for Small and Medium-Sized Enterprises in Colombia. Advanced Science Letters, 23(11), 10846-10849. Crossref

- Brun, A., Caniato, F., Caridi, M., Castelli, C., Miragliotta, G., Ronchi, S., \& Spina, G. (2008). Logistics and supply chain management in luxury fashion retail: Empirical investigation of Italian firms. International Journal of Production Economics, 114(2), 554-570. Crossref

- Carraresi, L., Mamaqi, X., Albisu, L. M., \& Banterle, A. (2016). Can strategic capabilities affect performance? Application of RBV to small food businesses. Agribusiness, 32(3), 416436. Crossref

- Ciliberti, S., Carraresi, L., \& Bröring, S. (2016). Drivers of innovation in Italy: food versus pharmaceutical industry. British Food Journal, 118(6), 1292-1316. Crossref

- Costa, R. V., \& Ramos, A. P. (2015). Designing an AHP methodology to prioritize critical elements for product innovation: an intellectual capital perspective. International Journal of Business Science \& Applied Management, 10(1). 15-34

- Dangelico, R. M., Pujari, D., \& Pontrandolfo, P. (2017). Green Product Innovation in Manufacturing Firms: A Sustainability-Oriented Dynamic Capability Perspective. Business Strategy and the Environment, 26(4), 490-506. Crossref

- Danneels, E. (2002). The dynamics of product innovation and firm competences. Strategic management journal, 23(12), 1095-1121. Crossref

- Droge, C., Vickery, S.K. \& Jacobs, M.A. (2012). Does supply chain integration mediate the relationships between product / process strategy and service performance? An empirical study. Intern. Journal of Production Economics, 137(2), 250-262. Crossref

- Ettlie, J.E. \& Reza, E.M. (1992). Organizational Integration and Process Innovation. Academy of Management Journal, 35(4), 795-827. Crossref

- Ferdinand, Augusty. (2014). Metode Penelitian Manajemen:Pedoman Penelitian untuk Penulisan Skripsi, Tesis dan Disertasi Ilmu Manajemen. Edisi 5. Semarang: Badan Penerbit Universitas Diponegoro.

- Garcia-Morales. V. J. Llorens-Montes. F.J. (2006). "Antecedent and consequences of organizational innovation and organizational learning in entrepreneurship". Industrial Management dan data system, 106(1), 21-42. Crossref

- Garengo, P., \& Panizzolo, R. (2013). Supplier involvement in integrated product development: evidence from a group of Italian SMEs. Production Planning \& Control, 24(23), 158-171. Crossref

- Goyal, V. K. (2001). Multiple description coding: Compression meets the network. IEEE Signal processing magazine, 18(5), 74-93. Crossref 
- Gray, J. R., Braver, T. S., \& Raichle, M. E. (2002). Integration of emotion and cognition in the lateral prefrontal cortex. Proceedings of the National Academy of Sciences, 99(6), 4115-4120. Crossref

- Gunaratne, A., \& Hoover, R. (2002). Effect of heat-moisture treatment on the structure and physicochemical properties of tuber and root starches. Carbohydrate polymers, 49(4), 425-437. Crossref

- Hills, G. E., Hultman, C. M., \& Miles, M. P. (2008). The evolution and development of entrepreneurial marketing. Journal of Small Business Management, 46(1), 99-112. Crossref

- Hubeis, M. (2005). Manajemen kreativitas dan Inovasi dalam Bisnis. PT. Hecca Mitra Utama, Jakarta.

- Indrajit, Richardus Eko dan Richardus Djokopranoto. (2006). Konsep Manajemen Supply Chain ,Cara Baru Memandang Mata Rantai Penyediaan Barang Edisi 4. Jakarta: Grasindo.

- Jebarus, F. (2001). Konsep supply chain management. Impian menarik dengan segudang tuntutan. Usahawan, 30(2), 18-21.

- Kartikasari, D., Dewanto, A., \& Rochman, F. (2014). Pengaruh Kualitas Layanan terhadap Kepuasan dan Kepercayaan di Rumah Sakit Bunda Kandangan Surabaya. Jurnal Aplikasi Manajemen, 12(3), 454-463.

- Kasali, R. (2010). Myelin: mobilisasi intangibles menjadi kekuatan perubahan. PT Gramedia Pustaka Utama.

- Khan, Y. K., Kamaruddin, L. M., \& Buyung, S. Z. (2017). The Effects of Structural Capital on Organisational Innovation in Australian SMEs. Advanced Science Letters, 23(9), 84628465. Crossref

- Kotler, P. (2005). Management trienja. Organizacija/ Journal of Management, Informatics and Human Resources, 38(10), 639-650

- Koufteros, X., Vonderembse, M. \& Jayaram, J. (2005). Internal and external integration for product development: The contingency effects of uncertainty, equivocality,. Decision Science, 36(1), 97-133. Crossref

- Li, S., Ragu-Nathan, B., Ragu-Nathan, T. S., \& Rao, S. S. (2006). The impact of supply chain management practices on competitive advantage and organizational performance. Omega, 34(2), 107-124. Crossref

- Liu, Y. H., Yang, K. F., Kuo, P. C., Chung, M. T., Chen, H. Y., Wu, T. J., \& Chiou, W. C. (2017). U.S. Patent No. 9,773,701. Washington, DC: U.S. Patent and Trademark Office.

- Machfoedz, M. U., \& Machfoedz, M. (2004). Kewirausahaan suatu pendekatan kontemporer. Yogyakarta: UPP AMP YKPN.

- Martini, A., Neirotti, P., \& Appio, F. P. (2017). Knowledge searching, integrating and performing: always a tuned trio for innovation?. Long Range Planning, 50(2), 200-220. Crossref

- O'Regan, N., \& Ghobadian, A. (2005). Innovation in SMEs: the impact of strategic orientation and environmental perceptions. International Journal of Productivity and Performance Management, 54(2), 81-97. Crossref

- Paulraj, A., Chen, I. J., \& Blome, C. (2017). Motives and performance outcomes of sustainable supply chain management practices: A multi-theoretical perspective. Journal of Business Ethics, 145(2), 239-258. Crossref

- Penniston, K. L., Antonelli, J. A., Viprakasit, D. P., Averch, T. D., Sivalingam, S., Sur, R. L., ... \& Nakada, S. Y. (2017). Validation and reliability of the Wisconsin stone quality of life questionnaire. The Journal of urology, 197(5), 1280-1288. Crossref

- Petersen, K.J., Handfield, R.B., Ragatz, G.L. (2005). Supplier integration into new product development: Coordinating product, process, and supply chain design. Journal of Operations Management, 23(3/4), 371-388. Crossref

- Pituringsih, E. (2010). Tinjauan Konseptual: Criteria Supplier-Selection, Integrasi Internal dan Eksternal Supply Chain Terhadap Kinerja Perusahaan. Akuntansi Multiparadigma, 1. Crossref 
- Prajogo, D. \& Olhager, J. (2012). Supply chain integration and performance: The effects of long-term relationships, information technology and sharing, and logistics integration. International Journal of Production Economics, 135(1), 514- 522. Crossref

- Purnama, C., \& Subroto, W. T. (2016). Competition intensity, uncertainty environmental on the use of information technology and its impact on business performance small and medium enterprises (SMEs). International Review of Management and Marketing, 6(4).

- Pustynnikova, E. V., \& Uskova, E. O. (2017). The Formation of Competitive Advantages for Corporate Structures Based on the Cluster Integration. Ėkonomika Regiona, 13(2), 500510. Crossref

- Quang, H. T., Sampaio, P., Carvalho, M. S., Fernandes, A. C., Binh An, D. T., \& Vilhenac, E. (2016). An extensive structural model of supply chain quality management and firm performance. International Journal of Quality \& Reliability Management, 33(4), 444-464. Crossref

- Ragatz, G.L., Handfield, R.B. \& Scannell, T. V. (1997). Success Factors for Integrating Suppliers into New Product Development. Journal of Product Innovation Management, 14(3), 190-202. Crossref

- Rahmah, M., \& Fatmah, D. (2018). Organizational Culture and Intrapreneurship Employee of the Impact on Work Discipline of Employees in Brangkal Offset. Jurnal Ilmu Manajemen dan Bisnis, 10(1), 1-8. Crossref

- Restrepo, J. A., Gómez, S. M., \& VANEGAS, J. G. (2016). The SMEs' internationalization: Multicriteria-Based Priorization Using Fuzzy Logic. Revista ESPACIOS. 37 (07), 21-29

- Robbins, S. P., \& Coulter, M. (2010). Management. Pearson Education.

- Russell, S. N., \& Millar, H. H. (2014). Exploring the relationships among sustainable manufacturing practices, business performance and competitive advantage: Perspectives from a developing economy. Journal of Management and Sustainability, 4(3), 37-53 Crossref

- Schmelzle, U., \& Tate, W. L. (2017). Integrating External Knowledge: Building a Conceptual Framework of Innovation Sourcing. Transportation Journal, 56(4), 477-512. Crossref

- Seles, B. M. R. P., de Sousa Jabbour, A. B. L., Jabbour, C. J. C., \& Dangelico, R. M. (2016). The green bullwhip effect, the diffusion of green supply chain practices, and institutional pressures: Evidence from the automotive sector. International Journal of Production Economics, 18(2), 342-355. Crossref

- Setiawan, M., Emvalomatis, G., \& Lansink, A. O. (2012). The relationship between technical efficiency and industrial concentration: Evidence from the Indonesian food and beverages industry. Journal of Asian Economics, 23(4), 466-475 Crossref

- Song, Y., Feng, T., \& Jiang, W. (2017). The Influence of Green External Integration on Firm Performance: Does Firm Size Matter?. Sustainability, 9(8), 1328-1338 Crossref

- Tarabieh, S. M., Ahmad, Z. A., \& Siron, R. (2015). The Synergistic Impact of Customer Orientation and Supplementary Services on Competitive Advantage and Organizational Performance (Pilot Survey). International Review of Management and Business Research, $4(2), 484-496$

- Teece, David J. (2007) "Explicating Dynamic Capabilities: The Nature and Microfoundations of (Sustainable) Enterprise Performance." Strategic Management Crossref

- Tehseen, S., \& Ramayah, T. (2015). Entrepreneurial competencies and SMEs business success: The contingent role of external integration. Mediterranean Journal of Social Sciences, 6(1), 50-61 Crossref

- Thatte, A. A. (2007). Competitive advantage of a firm through supply chain responsiveness and SCM practices (Doctoral dissertation, University of Toledo).

- Thoo, A. C., Sulaiman, Z., Choi, S. L., \& Kohar, U. H. A. (2017, June). Understanding Supply Chain Management Practices for Small and Medium-Sized Enterprises. In IOP Conference Series: Materials Science and Engineering 215(1), 1-9 Crossref 
Chamdan Purnama, Ludi Wishnu Wardana, Yusriyah Rahmah, Dinda Fatmah, Mirhamida Rahmah

The Impact of External Integration and Internal Integration to Product Innovation and Competitive Advantage on Small and Medium Enterprises (SMEs)

- Thun, J-H. (2010). Angles of integration: An empirical analysis of the alignment of internetbased information technology and global supply chain integration. Journal of Supply Chain Management, 46(2), 30-44. Crossref

- Tracey, M. (2004). A holistic approach to new product development: new insights. Journal of Supply Chain Management, 40(3), 37-55. Crossref

- Usvita, M. (2015). Pengaruh Orientasi Kewirausahaan dan Orientasi Pasar terhadap Kinerja Pemasaran melalui Keunggulan Bersaing sebagai Variabel Intervening (Survey pada UKM Pangan Dinas PERINDAGTAMBEN Kota Padang). E-jurnal Apresiasi Ekonomi, 3(1), 31-37.

- Utaminingsih, A. (2016). Pengaruh Orientasi Pasar, Inovasi, Dan Kreativitas Strategi Pemasaran Terhadap Kinerja Pemasaran Pada UKM Kerajinan Rotan Di Desa Teluk Wetan, Welahan, Jepara. Media Ekonomi dan Manajemen, 31(2), 77-87

- Vijayasarathy, L.R. (2010). Supply integration: An investigation of its multidimensionality and relational antecedents. International Journal of Production Economics, 124(2), 489505. Crossref

- Wong, C.W.Y. (2009). Complementarities and alignment of information systems management and supply chain management. International Journal of Shipping and Transport Logistics, 1(2), 156-171. Crossref

- Wong, C.W.Y., Wong, C.Y. \& Boon-itt, S. (2013). The combined effects of internal and external supply chain integration on product innovation. International Journal of Production Economics, 146(2), 566-574. Crossref

- Wong, C.Y., Boon-itt, S. \& Wong, C.W.Y. (2011). The contingency effects of environmental uncertainty on the relationship between supply chain integration and operational performance. Journal of Operations Management, 29(6), 604-615. Crossref

- Wu, GC. (2013). The influence of green supply chain integration and environmental uncertainty on green innovation in Taiwan's IT industry. Supply Chain Management: An International Journal, 18(5), 539-552. Crossref

- Yee-Loong Chong, A., \& Ooi, K. B. (2008). Adoption of interorganizational system standards in supply chains: an empirical analysis of RosettaNet standards. Industrial Management \& Data Systems, 108(4), 529-547. Crossref 